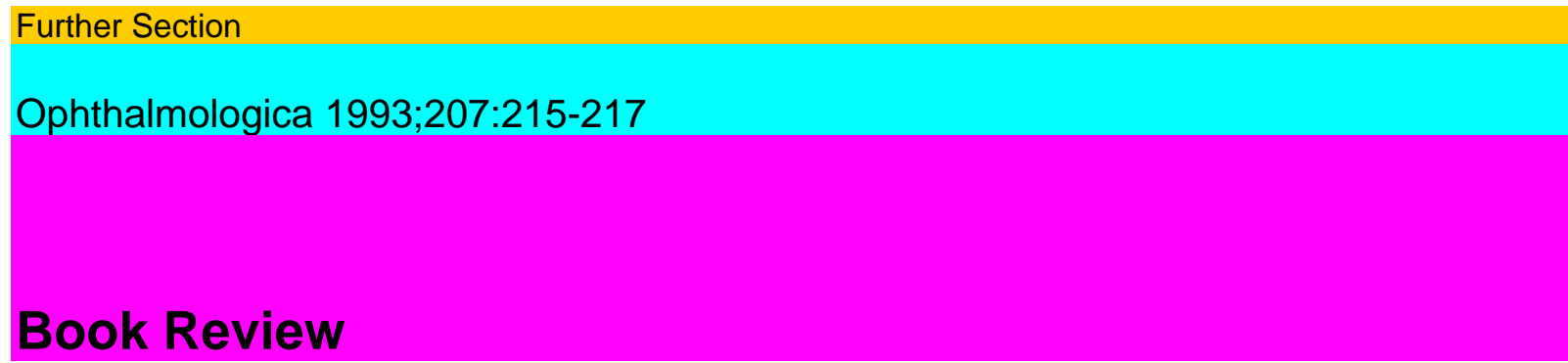

\title{
Jean Sedan
}

Post-cure de Tamblyope rééduqué

Masson, Paris 1992 VI+ 230 pp.; FFr.180.-ISBN 2-225-83893-3

La poste-cure de Гamblyope rééduqué a été publiée pour la premiere fois en 1958.

La reeducation de $\Gamma$ amblyopie par inhibition ou par un trouble de la localisation spatiale était alors un des principaux sujets d'intérêt de Гactualité ophtalmolo-gique.

Le but de Touvrage était de presenter à $\Gamma$ amblyope des exercices de correction de texte gradués, de recherche de forme dans un ensemble pour lever Гín-hibition, et de lecture en verticalité ou obliquité pour lever la concurrence spatiale.

La technique la plus utilisée, la correction de texte, nécessite une bonne pratique de la lecture et une bonne connaissance de Torthographe, ce qui est de moins en moins frequent. Le livre d'ailleurs est recommandé au-delà de 12 ans.

On peut discuter en dehors des cas particuliers, de la poursuite d'une reeducation à cet age. Cependant, la réédition de Touvrage tend à démontrer que nombreux encore sont les ophtalmologistes et les malades à pour-suivre une reeducation à long terme.

H. Saraux, Paris

Helmut Höh

Anisomyopie

Neue Aspekte in Diagnostik und Therapie

Contactologia-Bücherei, vol. 5

Enke, Stuttgart 1992

XIV+ 191 pp., 82 Abb., 53 Tab., DM 80-

ISBN 3-432-9986-9

Die Monographic «Anisomyopie», ein Beiheft der Zeitschrift «Contactologia», schliesst eine Lücke in der deutschen ophthalmologischen Literatur und weist gleichzeitig auf eine in der augenärztlichen Praxis und in der Klinik wichtige Krankheit hin, an der 500000-

1000000 Patienten allein in Deutschland leiden. Ziel des Autors ist es, dem Augenarzt einen Leitfaden für die heute zur Verfügung stehenden diagnostischen und therapeutischen Verfahren zu geben. Die Gliederung des Werkes mit vielen Unterkapiteln ist klar und über-sichtlich. Der Autor beleuchtet die Anisomyopie an-hand umfangreicher eigener Beobachtungen nicht nur von der optischen Seite her, sondern legt besonderen Wert auf das Binokularsehen und das damit verbunde-ne Problem der Aniseikonie. Beí den untersuchten Patienten werden auch viele andere Befunde, wie Exophthalmometrie, B-Bild-Sonographie, kraniale Computertomographie , Akkommodationsbreiten-messung, Interferenzsehschärfenbestimmung, entop-tische Funktionsprüfung sowie eine genaue Darstel-lung der Morphologie der verschiedenen Augenabschnitte mitgewertet. Eine Stufentherapie der Anisomyopie bei Kindern und Erwachsenen, abhän-gig, ob die Berechnungsdifferenz weniger oder mehr als 6 dpt beträgt, wird vorgeschlagen. Wichtig ist die Vollkorrektur des höhermyopen Auges mit Brille oder Kontaktlinse, wobei die Kontaktlinse durch die gering-ste Aniseikonie die besten 
Voraussetzungen für die Entwicklung eines hochwertigen beidäugigen Sehens bietet. Eventuell sind iseikonisierende Systeme oder refraktive Chirurgie einzusetzen. Eine vorhandene Amblyopie erfordert eine Okklusionstherapie und möglicherweise orthoptische Massnahmen. Bei aus-bleibendemVisusanstiegoder bei maligner Anisomyopie sind Aniseikoniemessungen, am besten mit dem Phasendifferenzhaploskop nach Aulhorn, notwendig. Um die Anisomyopie im Kindesalter rechtzeitig zu er-kennen, wird eine eigenständige augenärztliche Vorsorgeuntersuchung gefordert. Das umfangreiche Lite-raturverzeichnis umfasst 754 Arbeiten. Ein ausführli-ches Stichwortregister erleichtert das Nachschlagen. Man kann Herrn Ehrich, der das Geleitwort verfasste, nur zustimmen, dass dieses Buch Augenärzten in der täglichen Praxis hilfreich sein wird, und dem Werk, wie Herr Ruprecht im Grusswort schrieb, eine weite Verbreitung wünschen. Sicher wird diese umfassende Monographic auch dem Kliniker, besonders wenn er sich mit Fragen des Binokularsehens beschäftigt, und dem Assistenten in der Weiterbildungszeit ein wertvoller Ratgeber sein.

W. Aust, Kassel

215

Iriving Fatt, Barry A. Weissman

Physiology of the Eye

An Introduction to the Vegetative Functions;

2nd ed.

Butterworth Heinemann, Oxford 1992

$\mathrm{XI}+276$ pp.; E25.00

ISBN 0-7506-9085-2

This book with the subtitle An Introduction to the Vegetative Function has been primarily written for op-tometry students. The authors define vegetative physiology of the eye as those processes operating to maintain the viability of the eye against forces that can break down the organ's tissues.

Chapter 1 starts with a 15-page review of ocular anatomy. The chapters on aqueous humor, vitreous body, lens, sclera and retina have an introductory character. Chapters 6 and 7 on the cornea are more extensive. Of the 245 pages of text these two chapters cover 107 pages. More comprehensively is also dealt with the intraocular pressure (chapter $3 ; 45$ pages) and the protective mechanism of the eye (chapter 10; 18 pages).

The book is of value especially for the comprehensive information in the two chapters on the physiology of the cornea. The first chapter on the cornea deals with form, swelling, pressure and optics. The second deals with the metabolism of the cornea, particularly with the oxygen and carbon dioxide metabolism of the cornea under normal conditions as well as during contact lens wearing. These chapters give much basic information on the functions of the cornea to all who are interested in healthy and diseased cornea.

W.A. Houtman, Groningen

Mark J. Kupersmith

Neurovascular IMeuro-Ophthalmology

Springer, Heidelberg 1993

XVIII + 554pp., 284 fig., 61 tab., DM 398.-

ISBN 3-540-55636-2

Neurovascular neuro-ophthalmology is a branch of neuro-ophthalmology which particularly deals with complications that result from disorders that alter the intraorbital and intracranial circulation. As the authors write in their preface, no one medical speciality can effectively 
manage these neurovascular neuro-ophthalmology disorders alone. The complexity of diagnosis and treatment planning requires a multidisciplin-ary approach by neuroradiologist, neurosurgeon, neurologist and ophthalmologist in order to diagnose and treat the patients concerned.

The contents of the book have been very conveniently arranged. The first chapter gives a precise and detailed description of the vascular anatomy of the eye, orbita, cranial nerves of the brain region which are of neuro-ophthalmologic importance. Schematic drawings, pictures of anatomical and electron micrographic preparations and numerous angiograms support the text and are highly enlightening.

The other nine chapters dealing with the various disorders and diseases are well ordered and are clearly arranged along a fixed outline. Every topic starts with clinical features, followed by pathology and/or dysfunction, the various methods of neuro-imaging, the course and/or treatment.

There are comprehensive chapters on carotid cavernous fistulas, neuro-ophthalmic manifestations of intracranial dural venous disorders, orbital vascular lesions, and aneurysms involving the motor and sensory visual pathways, vascular malformations of the brain, and of embolic and noninflammatory occlusive vascular disease and ocular motor systems. Most of the topics in these chapters are well illustrated by photographs of clinical signs and pictures of the various neuro-imaging methods and ultrasonography.

Chapter 5 deals with vascular optic neuropathies. Anterior ischemic neuropathy, radiation damage to the eye and giant cell arteritis are extensively discussed. Other topics such as Leber optic neuropathy, low-tension glaucoma are briefly mentioned.

Chapter 9 on inflammatory vascular disorders of the brain and the eye reviews systemic diseases such as polyarteritis nodosa, systemic lupus erythematosus, Wegener's granulomatosis but also mentions Eales' disease, acute posterior multifocal placoid pigment ep-itheliopathy and others. The last chapter deals with migraine.

This beautiful book can be highly recommended to all who are concerned with neuro-ophthalmic problems.

W.A. Houtman, Groningen

216

L. S. Regenbogen, H. E. Eliahou Diseases Affecting the Eye and the Kidney

Basel, S. Karger, 1993

XVIII+ 458 pp. ;sFr. 448.-,

DM 537.-,

US $\$ 358.50$

ISBN 3-8055-5660-8

Thanks to the large number of authors, it was possible for the editors to describe virtually all disease entities which can afflict the eyes as well as the kidneys. Each disease entity is dealt with in a separate short chapter. The 'Table of Contents' is clear and well arranged, providing an easy survey of all diseases which can involve both organ systems. The book is supplemented by a subject index. With regard to content and presentation this book is outstanding, and all chapters contain a wealth of information representing the current state of knowledge. It is less a textbook than a reference source for the clinician. The literature recommendations following each chapter allow the reader to delve more deeply into the individual disease entities.

As is often the case in multiauthored books, the presentation in individual chapters does not always conform uniformly to an overall style. Additional illustrations of the ocular findings, perhaps even color fundus photographs, would have facilitated reading. 
Despite these slight weaknesses, I consider this book successful and highly recommendable. Den Herausgebern ist es gelungen, mit Hilfe einer grossen Zahl von Autoren praktisch sämtliche Krank-heitsbilder zu beschreiben, welche sowohl die Augen wie auch die Nieren befallen können. Jedes Krank-heitsbild ist in einem separaten kurzen Kapitel abge-handelt. Das Inhaltsverzeichnis ist klar und übersicht-lich und gibt einen schnellen Überblick über all die Krankheiten, welche beide Organsysteme befallen können. Das Buch wird durch ein Inhaltsverzeichnis ergänzt. Inhaltlich und gestalterisch ist das Buch her-vorragend und enthält eine Fülle von Informationen. Diese sind in sämtlichen Kapiteln auf dem neuesten Stand der Wissenschaft. Es ist weniger ein Lehrbuch als vielmehr ein Nachschlagewerk für den Kliniker. Lite-raturangaben nach jedem Kapitel ermöglichen es dem Leser, sich weiter in die einzelnen Krankheitsbilder zu vertiefen.

Wie oft bei «Vielautorenbüchern» sind die einzelnen Kapitel leider nicht immer genau gleich gestaltet. Weitere Abbildungen der Augenbefunde, vielleicht

sogar farbige Fundusfotos, würden das Lesen erleich-tern.

Trotz dieser kleinen Nachteile betrachte ich dieses Buch als gelungen und als sehr empfehlenswert.

Josef Flammer, Basel

Mark T. Watts, Michael E. Nelson External Eye Disease: A Colour Atlas

Churchill Livingstone, Edinburgh 1992106 pp.; E42.-ISBN 0-443-0446-5

Upon reviewing the book External Eye Disease: A Colour Atlas, one is first struck by the appropriateness of its title. This book is certainly a color atlas of external eye disease and external eye disease as it relates to systemic disease. The authors very candidly admit in their preface that the book is not intended to be an authority on external eye disease in regard to its text, but its primary goal is to allow a quick recognition of external eye diseases. The book not only is informative for those who are in the learning phases of their ophthalmology training, but is also a valuable reference for ophthalmologists who are presently in practice. Most of the conditions presented in the photographs are conditions which can be seen regardless of the nature of the practice and are not uncommon. There are, however, some of the rarer conditions that one may see, such as the corneal dystrophies and the squamous cell carcinoma. Although the text is very brief, this was the intention of the authors, and it is accurate in its brevity. It also has an excellent section on blepharitis and the types of blepharitis. Treatment is not given for the conditions, except in the most brief fashion, but again this was the intention of the authors. I feel that the atlas provides a valuable reference and would be an excellent addition to one's reference library within the office setting. It allows one to have a quick overview of some conditions, and the photographs, for the most part, are of excellent quality. There are a very few photographs where the condition being described is very difficult to discern. The atlas would be handy in training programs as well as in the private ophthalmologist's office and even for primary care physicians who have an interest in ophthalmology.

M. Miller-Meeks, Ann Arbor 